\title{
1 Establishing peach trees for organic production in Utah and the
}

\section{Intermountain West}

3

4 J.R. Reeve ${ }^{1}$, C.M. Culumber ${ }^{2}$, B.L., Black ${ }^{1}$, A.Tebeau ${ }^{3}$, C.V. Ransom ${ }^{1}$, D. Alston ${ }^{3}$, M. Rowley ${ }^{1}$, $5 \quad$ T. Lindstrom ${ }^{1}$.

6

$7 \quad{ }^{1}$ Department of Plants, Soils and Climate, Utah State University, Logan, UT 84322.

$9{ }^{2}$ University of California Cooperative Extension, Fresno County, 550 E. Shaw Avenue, Suite 10 210-B Fresno, CA 93710.

11

$12{ }^{3}$ Department of Biology, Utah State University, Logan, UT 84322.

14 Additional key words. Organic stone-fruit establishment, tree growth, soil fertility.

16 Abstract. Adequate weed control and nutrient supply are critical for successful establishment of

17 fruit trees. This is of particular concern in organic orchard establishment. In order to determine

18 the best approach for establishing peach trees (Prunus persica L.) organically in climates

19 characterized by hot dry summers and cold winters such as the North American Intermountain

20 West, seven organic and three integrated and conventional treatment combinations were

21 established in two first leaf orchards at the USU Kaysville Research Farm, Utah, in 2008 and

22 2009. Treatments consisted of different tree-row and alleyway mulch and fertilizer combinations.

23 Compost or conventional fertilizer (16-16-16 and urea) were applied at a baseline rate of 4.9, 9.6, 
$2419 \mathrm{~g}$ and $114 \mathrm{~g}$ of available nitrogen $(\mathrm{N})$ per $1^{\text {st }}, 2^{\text {nd }}, 3^{\text {rd }}$ and $4^{\text {th }}$ leaf tree respectively and

25 adjusted up or down on a plot basis based on tree growth. Compost was supplemented with a

26 feather meal 13-0-0 fertilizer starting in year three to avoid over application of phosphorus (P)

27 and potassium (K). Organic experiment tree growth was initially slowed by living and straw

28 mulches present in the tree-row. By 2011, $3^{\text {rd }}$ leaf trees were largest in treatments with Birdsfoot

29 trefoil alleyways, despite considerable tree-row weed/living mulch pressure. In the integrated

30 experiment, trees were larger in the compost plus conventional herbicide compared to

31 conventional fertilizer and herbicide treatment. Paper mulch depressed tree growth in

32 combination with both compost and conventional $\mathrm{N}$ sources, but more so in combination with

33 compost and organic herbicide where weed control was moderate. Weed pressure not lack of $\mathrm{N}$

34 was determined to limit organic tree growth in this study. A trefoil alleyway may alleviate the 35 need for intensive weed control when establishing organic peach orchards.

\section{Introduction}

39 The United States (US) market for organic produce continues to grow despite the recent

40 economic downturn (Dimitri and Oberholtzer, 2009; Slattery et al., 2011). Growth in tree fruits

41 and berries has been particularly strong with organic peach production increasing by 116 percent

42 between 2008 and 2011 (Perez and Plattner, 2013). Organic production in the US has largely

43 failed to keep pace, and meeting consumer demand continues to be a challenge (Dimitri and

44 Oberholtzer, 2009). Utah and the Intermountain Western US are traditional producers of high

45 quality tree fruit with high elevations, warm daytime temperatures and cool nights during the

46 summer, resulting in fruit that is exceptionally sweet and flavorful. Overall fruit production has 
47 dwindled in recent years due to urbanization and changing markets, although the planted area of

48 tart cherries and peaches has remained stable (Ernst et al., 2012; Utah Fruit and Berry Survey,

49 2006). The arid climate of the Intermountain West with relatively low disease pressure confers

50 considerable advantages for organic production and growing urban centers provide access to

51 markets. Currently, certified organic tree fruit in Utah is limited to a few very small producers,

52 however. Challenges include a lack of local expertise, short growing seasons with cold winters

53 and shallow alkaline soils low in organic matter. Strengthening an organic tree fruit industry in

54 the region will require locally adapted best management strategies, something that is currently

55 lacking.

A major challenge to establishing new organic orchards is the transition process.

58 Successful organic production requires growers manage soil reserves of readily available

59 nutrients as most organic fertilizers mineralize slowly in the short-term. Building sufficient soil

60 nutrient reserves can take time, especially in soils with very low native organic matter and high

$61 \mathrm{pH}$. Young fruit trees are particularly susceptible to competition from weeds which compete for

62 water and nutrients and often provide a refuge for pests (Skroch and Shribbs, 1986; Hoagland et

63 al., 2008, Tworkoski and Glenn, 2008). Bare soil or maintenance of an herbicide or tillage strip

64 is generally preferred during the orchard establishment phase in both organic and conventional

65 production (Welker and Glenn, 1991; Layne et al., 1994; Neilsen and Hogue, 2000; Tworkoski

66 and Glenn, 2008). Tillage along with applications of compost is a commonly used organic

67 orchard floor management system in the US (Hoagland et al., 2008). Adequate quantities of high

68 quality compost can be difficult and expensive to obtain, however, while frequent tillage has 
69 been shown to disrupt surface roots and tree stability, and reduce soil quality over the long term

70 (Skroch and Shribbs, 1986; Hoagland et al., 2008).

An alternative or complement to compost and other expensive organic inputs is to grow

73 legumes in the orchard (Granatstein and Sánchez, 2009; Rowley et al., 2011). Legumes are

74 capable of supplying significant $\mathrm{N}$ to fruit trees. Subterranean clover is used in coastal orchard

75 regions in the US because of its low growth habit. In a California study, subterranean clover

76 grown in the tree-row was found as effective as high $90 \mathrm{~kg} \mathrm{~N} \mathrm{ha}^{-1}$ applications of compost +

77 native vegetation for establishment of young peach trees at only a fraction of the cost of compost

78 (Meyer et al., 2006). Many growers in Colorado and Utah plant orchards into established alfalfa

79 and manage weeds by mowing. However, this practice has not been formally evaluated and has

80 generally been discouraged in peach orchards due to the potential for problems with pests,

81 particularly cat-facing insects (Killian and Meyer, 1984).

Legumes can also strongly inhibit tree growth through competition (Skroch and Shribbs,

84 1986; Hoagland et al., 2008; TerAvest et al., 2011). An Italian study showed that subterranean

85 clover inhibited early growth of peach trees compared to a tillage control (Antonelli et al., 1997).

86 Merwin and Stiles (1994) showed a similar competition problem with crown vetch planted in the

87 tree- row of establishing apple trees. In tart cherry, Sánchez et al. (2003) showed that legumes

88 incorporated into tree-row cover crop mixes did not increase yield relative to mixes with fewer

89 or no legumes. Although fertigation + living mulches reduced yield discrepancies in this

90 Michigan study. Stasiak and Rom (1991) indicated that competition effects may be short lived in

91 establishing peach orchards, however. In addition, locating the legumes in the alleyway versus 
92 the tree-row may be critical to reducing competition and optimizing benefits (Granatstein and

93 Sánchez, 2009; Mullinix and Granatstein, 2011).

94

95 There is also considerable interest in mulch, made from various organic and inorganic

96 materials, for weed control in organic orchards (Granatstein and Mullinix, 2008; Tworkoski and

97 Glenn, 2008: Cline et al., 2011; TerAvest et al., 2011). Hoagland et al. (2008) demonstrated good

98 weed control with wood chip mulch, although tree nutritional problems were observed and soil

99 quality was somewhat impaired. Use of woven fabric mulch was used successfully in sweet

100 cherry establishment (Nunez-Elisea et al., 2005) although Neilsen and Hogue (1992) showed

101 dramatic reductions in soil and leaf $\mathrm{K}$ in apple. Yield was highest in tart cherry systems receiving

102 supplemental grass legume mulch combined with glyphosate as needed (Sanchez, 2003). And

103 paper mulch significantly increased growth of apple (Hogue et al., 2010). Straw is effective for

104 weed control during raspberry establishment (Bushway et al., 2008) and may sufficiently cool

105 soil temperatures in the early spring to prevent premature bud break (Walsh et al. 1996; Wang et

106 al. 2015), an increasing problem in a changing climate. Mulches may also hold additional

107 benefits in terms of conserving soil moisture (Walsh et al. 1996; Wang et al. 2015). Increased

108 rodent activity is of potential concern, however (Sullivan et al. 1998).

109

110 The goal of this study was to evaluate orchard floor management practices for

111 establishing organic peach trees in environments characterized by hot dry summers, cold winters

112 and shallow alkaline soils such as the Intermountain Western US. Two orchards were established

113 in 2008 at the USU Kaysville Research Farm, Utah. A certified organic orchard was planted to

114 test the effects of living and straw mulches as weed management strategies in the tree-row in 
115 combination with grass or legumes grown in the alleyway. These treatments were compared to

116 common organic methods of maintaining weed free tree-rows, tillage and fabric mulch, with

117 grass alleyways. A second orchard was established to investigate the interaction between nutrient

118 availability from organic fertilizers and weed competition.

\section{Materials and Methods}

122 2.1 Site history, experimental design and management.

123 Two peach orchards (Prunus persica L.) were established in neighboring fields at the USU

124 Horticulture Research Station in Kaysville, UT (41 $1^{\prime} 16.73$ "N, 111 ${ }^{\circ} 55^{\prime} 43.37$ "W, 1336 m

125 elevation). The fields were fallow prior to 2005 and were then planted to a succession of summer 126 and winter cover crops to facilitate weed control. The soil type was a Kidman fine sandy loam.

127 In April 2008, the two sites were clear cultivated and the orchards planted. The organic

128 experiment was planted in twelve rows of 30 trees with $2.44 \mathrm{~m}$ in-row and $4.88 \mathrm{~m}$ between-row

129 spacing, in a randomized complete block design with four blocks. The integrated experiment was

130 planted in twelve rows of 25 trees with the same spacing and design described above. The

131 blocking factor represented cultivar ('Starfire' and 'Coralstar' on 'Lovell' rootstock) and

132 location within each orchard. Cultivars were planted in alternating blocks of three rows each

133 resulting in plots of $3 \times 5$ trees in size with six (organic) or five (integrated) treatments per block.

134 The three central trees in each 15 tree plot were designated as data trees; the surrounding trees

135 served as guard trees to protect the data trees from edge effects. This layout resulted in two guard 136 rows between data rows and two guard trees between data trees in a row. 
139 experiment: straw mulch with a grass alleyway (StGr), straw mulch and a Birdsfoot trefoil

140 (Lotus corniculatus) alleyway (StTr), living mulch (low-growing shallow rooted allysum,

141 Lobularia maritima) with grass alleyway (LmGr), living mulch and legume alleyway (LmTr),

142 woven plastic mulch (5oz. Dewitt, Sikeston, MI) with a grass alleyway (WfGr) and tillage with

143 grass alleyway (TiGr). Treatments assigned to the integrated experiment were: conventional

144 fertilizer plus herbicide (CfH), compost as organic fertilizer plus herbicide (OfH), conventional

145 fertilizer with paper mulch and reduced herbicide (CfM) and compost with paper mulch and

146 organic herbicide (OfM). All alleyways in the integrated experiment were planted to grass.

147 Treatments StGr, StTr, LmGr, and LmTr were managed according to the sandwich system

148 (Hoagland et al., 2008) with a narrow $0.3 \mathrm{~m}$ tilled strip maintained between the tree-row and

149 alleyway using a tractor mounted rototiller. In the organic experiment a significant number of

150 data trees failed to grow above the graft during the first season so all data-row trees were

151 replanted in April 2009.

Chicken manure compost was applied to all treatments in the organic experiment and

154 treatment $\mathbf{O f H}$ and OfM in the integrated experiment in 2008, and compost made of steer 155 manure, steer stomach contents upon slaughter and wood chips was applied in 2009-2011.

156 Compost was applied around the drip line of the tree within the tree-row in tillage, weed fabric,

157 herbicide and paper mulch treatments, and to the tillage strips in the straw and living mulch 158 treatments. Compost had a total $\mathrm{N}$ content of 1.89, 1.46, 2.25, and 2.10\% and a C:N ratio of 7:1,

159 13:1, 12:1 and 10.9 in 2008-2011 respectively (Table 1). Application rates in the organic 160 experiment were calculated to supply 17, 24, 32 and 51 g total $\mathrm{N}$ from 2008 to 2011 respectively, 
161 assuming available $\mathrm{N}$ of $20 \%$ in 2008 and 2009, $30 \%$ in 2010 and $25 \%$ in 2011. Application

162 rates in the integrated orchard were higher $(17,48,63$ and $51 \mathrm{~g} \mathrm{~N}$ from 2008 to 2011

163 respectively) due to the fact that the trees were one year older. Individual compost rates were

164 adjusted up or down on a plot basis relative to the base rate based on tree growth (Table 2). Due

165 to rapidly rising soil $\mathrm{P}$, the baseline rate of compost was limited to $2.26 \mathrm{~kg}$ per tree in 2011 and

166 the additional $\mathrm{N}$ provided through the application of an organically approved feather meal

167 product (NatureSafe 13-0-0, Irving, TX) in late May. Conventionally fertilized trees (CfH and

168 CfM) received 4.8, 9.6, 19.2g and 19.2g N in the form of 16-16-16, from 2008-2011 and an extra

$16995 \mathrm{~g} \mathrm{~N}$ in the form of urea (46-0-0) in 2011. Elemental sulfur (S) was applied to the soil at a rate

170 of $90 \mathrm{~g}$ per tree in early December 2010 due to low soil and leaf test $\mathrm{S}$ values. Tissue tests also

171 revealed trace element deficiencies so foliar applications of trace elements were applied equally

172 to all treatments as needed starting in 2009. An organic approved pest management program for

173 the control for peach twig borer, greater peach tree borer (pheromone-based mating disruption

174 and a microbial insecticide) and coryneum blight (copper) was instigated across both orchards in

175 2008. Horticultural oil for peach aphid control was applied in 2010 and 2011.

177 Fresh straw was added at a rate of $\sim 4 \mathrm{~kg}$ per tree to the straw treatments (StGr and $\mathbf{S t T r}$ )

178 in March 2008 and 2009. This rate was reduced to $2 \mathrm{~kg}$ per tree in 2010 and 2011. The straw

179 applied was either wheat (Triticum aestivum) or barley (Hordeum vulgare). Spray-on paper

180 mulch (Nature's Own organic hydro-seeding mulch, Hamilton Manufacturing Inc. Twin Falls,

181 ID) was mixed with water and applied with a hydro-seeder to treatments $\mathbf{C f M}$ and $\mathbf{O f M}$ in

182 March. The fabric mulch (WfGr) was rolled back each fall to prevent rodent damage to tree

183 trunks and replaced each March after fertilizers were applied. The alyssum planted in the living 
184 mulch plots (LmGr and LmTr) failed to re-establish following the winter of 2008, most 185 probably due to a late frost that killed the emerging seedlings. It was reseeded in 2009 and 2010 , 186 however, stands in those years were poor due to increasing perennial weed pressure, and in 2011 187 the living mulch treatment was allowed to generate spontaneously from weeds already present. 188 The alleyways were mowed approximately monthly and in the trefoil treatments (StTr and 189 LmTr) the clippings were blown into the tree-row and allowed to remain on the surface. Living 190 mulches and weeds in tree-rows were mowed as needed approximately monthly. The tillage 191 treatment (TiGr) was maintained by hand using a stirrup hoe approximately once per month. 192 Glyphosate herbicide was applied twice per year to the conventional and compost herbicide 193 treatments ( $\mathbf{C f H}$ and $\mathbf{O f H})$ and once per year to the paper mulch treatment (CfM) at rate of $1.5 \%$ 194 in spray volumes of 234 to $281 \mathrm{~L} \mathrm{ha}^{-1}$. A single application of a clove oil organic herbicide 195 (Matran, Ecosmart Technologies Inc, Ames, IA) was applied to the organic treatment with paper 196 mulch (OfM) according to label recommendations in 2009 and 2010. Acetic acid (Weed Pharm) 197 was applied to this treatment two times at a rate of $280 \mathrm{~L} \mathrm{ha}^{-1}$ in 2011 . Each plot was irrigated 198 independently using micro sprinklers. We previously found that orchard water use differed by 199 the species of orchard floor vegetation (Rowley et al. 2011). For this study, irrigation needs 200 were determined for each plot. Irrigation volumes to be applied were calculated based on soil 201 volumetric water content, measured each week per plot prior to irrigation, using a capacitance 202 probe (Diviner 2000, Sentek Technologies, Stepney, Australia). Hence soil moisture was 203 returned to field capacity each week to reflect actual water use by treatment. 
206 Trunk cross sectional area was calculated each winter using trunk diameters measured with a 207 forestry tape measure $30 \mathrm{~cm}$ above ground level, and canopy diameter, shoot elongation and 208 pruning weights determined each spring. Tree nutritional status was determined by analyzing a 209 random sample of the $3^{\text {rd }}$ fully expanded leaves in late July or early August. Leaf samples were

210 rinsed in $\mathrm{ddH}_{2} \mathrm{O}$ and dried at $70^{\circ} \mathrm{C}$ for 72 hours, ground to $<0.2 \mu \mathrm{m}$ with a UDY mill (UDY 211 corp, Fort Collings, CO). The leaf samples were analyzed for total $\mathrm{N}, \mathrm{P}, \mathrm{K}, \mathrm{Ca}, \mathrm{Mg}$ and trace

212 elements at the USU Analytical Lab (Logan, UT) in 2010 and Albion Laboratories (Clearfield, 213 UT) in 2011.

215 Soil nitrate $\left(\mathrm{NO}_{3}{ }^{-}\right)$and ammonium $\left(\mathrm{NH}_{4}{ }^{+}\right)$were determined during the growing season at 216 monthly intervals from May through August. Six random soil samples per plot were collected 217 from the tree-row $(0-30 \mathrm{~cm})$ with a $1.6 \mathrm{~cm}$ probe, combined, passed through a 2-mm sieve, 218 extracted immediately in $1 \mathrm{M} \mathrm{KCl}$ and measured on a QuickChem Lachat (Latchat Instruments, 219 Loveland, CO) using the sulfanilamide and phenate methods according to manufacturer's 220 instructions. Soil $\mathrm{pH}$, electrical conductivity (EC) and macro and micro elements were measured 221 yearly on air-dried soils in June according to Gavlak et al. (2003). Organic carbon (C) and 222 nitrogen $(\mathrm{N})$ were measured by dry combustion with PrimacsSNC total $\mathrm{C}$ and $\mathrm{N}$ analyzers

223 (Skalara, Inc, Buford, GA) on finely ground $(<0.2 \mu \mathrm{m})$ soil samples collected as above from 0-10 $224 \mathrm{~cm}$ depth. Inorganic $\mathrm{C}$ was found present in trace quantities only in the top $10 \mathrm{~cm}$ so total $\mathrm{C}$ was 225 assumed to equal organic $\mathrm{C}$.

\subsection{Statistical analyses.}

227 Tree growth, nutrient status and soil fertility in response to treatment were analyzed using an 228 incomplete randomized block design with two factors in PROC GLIMMIX in the SAS System 
229 for Windows (SAS Institute, Cary, NC). In the organic experiment, the factors were alleyway 230 and tree-row with time as repeated measures. Main effects were compared to weed-free control

231 treatments using contrast statements. In the integrated experiment, the two factors were fertilizer

232 type and method of weed control. When a significant tree-row $\mathrm{x}$ alleyway interaction was

233 detected all treatments within each experiment were analyzed as a one-way design with repeated

234 measures. In all cases experimental factors and time were modelled as fixed effects while block 235 was modelled as a random effect.

\section{Results and Discussion}

\section{$238 \quad 3.1$ Tree Growth.}

239 Weed fabric and tillage treatments initially increased tree trunk cross sectional area relative to 240 the living mulch treatments in the organic orchard (Figure 1). However, by 2011 trees grown 241 with trefoil alleyways ( $\mathbf{L m T r}$ and $\mathbf{S t T r})$ were as large as the weed free control treatments (TiGr 242 and $\mathbf{W f T r}$ ) while trees grown with grass alleyways ( $\mathbf{L m G r}$ and $\mathbf{S t T r})$ were significantly smaller.

243 This suggests that trees grown with trefoil in the alleyway were able to access more resources

244 (nutrients and water) than trees grown with a grass alleyway despite considerable weed pressure

245 in the tree-row (Table 3). In addition to $\mathrm{N}$ supplied by the compost and feather meal, trefoil

246 biomass blown into the tree-row generated an additional $0.1 \mathrm{~kg} /$ tree or $73 \mathrm{~kg}$ total $\mathrm{N} \mathrm{ha}^{-1}$ (Table

247 2). This more than doubled the total $\mathrm{N}$ applied to the trefoil treatments per year which could

248 possibly account for the additional tree growth. However, the amount of this surface deposited $\mathrm{N}$ 249 available for tree uptake is unclear (Ferreira et al., 2015). And increased tree growth could also 250 be associated with increased tree root growth and improved access to soil resources (Parker and 251 Mayer, 1996). Straw mulch helped to suppress weeds, and this was reflected in a modest increase 
252 in tree trunk cross sectional area (Figure 1, Table 3), overall however, tree growth was

253 dominated by legume alleyway effects.

254

255

Trials in New Zealand, Utah and Portugal showed orchard-grown legumes have the

256 potential to generate 80-194 $\mathrm{kg}$ total $\mathrm{N} \mathrm{ha}^{-1}$ (Goh et al., 1995; Rowley et al., 2011; Ferreira et al.,

257 2015). Legumes have also been shown to strongly inhibit tree growth through competition,

258 however (Skroch and Shribbs, 1986; Merwin and Stiles, 1994; Antonelli et al., 1997; Hoagland

259 et al., 2008; TerAvest et al., 2011). Effects of ground cover competition is known to be species

260 specific, with alfalfa less competitive with peach than many grasses (Parker et al., 1993; Parker

261 and Meyer, 1996). The reasons are unclear, but could relate to root morphology, specifically the

262 tap-rooted structure of alfalfa and other legumes such as Birdsfoot trefoil. Black et al., (2010)

263 showed that root growth of tart cherry in orchards managed with a grass alleyway was primarily

264 constrained to the area below the herbicide strip, confirming the need for weed control in

265 orchards managed with grass alleyways. Locating legumes in the alleyway versus the tree-row,

266 as in this study, may be critical to reducing competition in the alleyway, hence optimizing the

267 benefits of orchard-grown legumes and reducing tree susceptibility to weed pressure (Granatstein

268 and Sánchez, 2009; Mullinix and Granatstein, 2011).

In the integrated experiment, there were initially few differences between treatments in

271 tree trunk cross sectional area (Figure 2). By 2011, however, tree trunk cross sectional area in the

272 OfM treatment was lowest. No difference in trunk cross sectional area between the $\mathbf{O f H}$

273 treatment and the conventional treatment suggests that reduced tree growth in the OfM treatment

274 was caused by inadequate weed control rather than lack of $\mathrm{N}$ (Table 4). There were no 
275 differences between the CfM treatment and the conventional control indicating that paper mulch

276 was not immobilizing $\mathrm{N}$, at least with conventional fertilizer. Conventional trees in the integrated

277 experiment transitioned to organic management beginning in 2011, quickly became chlorotic and

278 stunted compared to other conventionally managed trees (data not shown). This illustrates the

279 challenges associated with transitioning mature trees to organic production on soils that are

280 naturally low in organic matter with poor nutrient reserves.

281

$282 \quad 3.2$ Soil Properties.

283 Soil properties in the tree-row responded positively to compost additions, cover crops, and

284 organic mulches in both experiments. Similar results have been demonstrated in response to

285 orchard ground cover and mulch in a range of climates and soil types (Sanchez et al., 2003;

286 Hoagland et al., 2008; Tworkoski and Glenn, 2008; Ramos et al., 2011; TerAvest et al., 2011). In

287 the organic experiment in Utah, total organic soil C significantly increased in the top $10 \mathrm{~cm}$ in

288 the trefoil treatment two years after establishment, while increased total organic $\mathrm{N}$ was seen in

289 response to trefoil by the third year (Figure 3 and 4). Weed fabric also appeared to improve soil

290 C but only in one year out of four. While both straw and living mulch increased soil C and $\mathrm{N}$

291 compared to tillage and weed fabric, there were no differences between straw and living mulch.

292 Compost consistently increased soil total C and N compared to conventional fertilizer beginning

293 from orchard establishment (Figure 5). Significant effects of paper mulch on total C were not

294 apparent until year three, however, with no differences measured in total N (data not shown).

295

296

Available $\mathrm{N}\left(\mathrm{NO}_{3}{ }^{-}\right.$and $\left.\mathrm{NH}_{4}{ }^{+}\right)$in the tree-row varied considerably between treatments and

297 year, although trefoil increased soil $\mathrm{NO}_{3}{ }^{-}$in three out of four years (data not shown). These 
298 findings are in contrast to Ferreira et al. (2015), who found no increase in soil $\mathrm{N}$ as a result of 299 surface deposited legume residue. Compost increased soil $\mathrm{NO}_{3}{ }^{-}$relative to conventional fertilizer

300 in 2009 with the opposite effect in 2011. In general soil $\mathrm{NO}_{3}{ }^{-}$levels were low (below $15 \mathrm{mg} \mathrm{kg}^{-1}$ ) 301 suggesting a tight coupling between $\mathrm{N}$ mineralization and tree uptake in the tree-row. Nutrient 302 status in the alleyway was not measured in this study.

Available soil $\mathrm{P}$ and $\mathrm{K}$ increased dramatically (2-3x baseline levels) within one year of compost application (Figures 6 and 7) well above the recommended levels of 10-30 and 75-400

$306 \mathrm{mg} \mathrm{kg}^{-1}$ for $\mathrm{P}$ and $\mathrm{K}$ respectively (Cardon et al., 2008). For this reason, compost rates were 307 reduced in 2011 with supplemental $\mathrm{N}$ supplied through additions of feather meal. Elevated soil P 308 is associated with inhibition of trace element uptake as well as surface water eutrophication 309 (Marschner, 1995; Alloway, 2009). Elevated soil K can compete with Ca and Mg uptake and 310 reduce fruit quality, particularly in apple (Marschner, 1995; Mercelle, 1995). This reflects the 311 challenge of relying on compost alone for soil fertility, even if adequate quantities are cheaply

312 available. Once compost applications were reduced to meet projected orchard P as opposed to N

313 needs, soil available $\mathrm{P}$ and K returned to more acceptable levels. Alleyway treatment effects on 314 soil $\mathrm{P}$ were non-significant, and tree-row effects highly variable by year, although there was a 315 tendency for straw mulch to increase soil available P. Both straw and trefoil had a tendency to 316 increase soil available K, although again, year to year variability was high thus making 317 interpretation difficult.

Other soil macro and micro elements were highly variable by year with few clear 320 treatment patterns emerging. Living mulch increased soil $\mathrm{Ca}$ and $\mathrm{Mg}$ relative to straw mulch in 
321 two out of four years while trefoil increased available soil Mn. In the integrated experiment,

322 compost increased soil $\mathrm{Ca}, \mathrm{Mg}$, $\mathrm{Na}$, and $\mathrm{S}$ in 2009 and 2010, and $\mathrm{Cu}$ and $\mathrm{Zn}$ in 2010. When

323 compost rates were reduced in 2011, differences largely disappeared, however (data not shown).

324 Soil $\mathrm{pH}$ at this site remained at 8.0 throughout with no treatment effects noted in any of the 325 treatments in either orchard.

\subsection{Tree leaf nutrients.}

328 Tree leaf nutrients also varied chiefly by year as opposed to treatment. In the organic experiment

329 there were no treatment effects on tree leaf N. Legumes have been associated with excessive late

330 season $\mathrm{N}$ uptake which can contribute to winter bud kill and fruit quality problems (Tworkoski

331 and Glenn, 2008). This was not observed in our study, perhaps because of low native soil organic

332 matter. Growers in Utah frequently apply $\mathrm{N}$ in the fall to increase tree growth in the spring due to

333 low native soil reserves. Leaf $\mathrm{P}$ was significantly greater in grass and weed fabric treatments

334 compared to trefoil, with tillage intermediate. Trefoil treatments had greater leaf $\mathrm{K}$ than grass

335 and weed fabric in 2010 and greater leaf $\mathrm{K}$ than tillage and weed fabric in 2011. In the

336 integrated experiment, paper much reduced tree leaf $\mathrm{N}$ in 2009 , although not to deficiency levels,

337 and conventional fertilizer increased tree leaf $\mathrm{N}$ over compost in 2011. Compost increased tree

338 leaf $\mathrm{P}$ in all years, $\mathrm{K}$ in 2009 and 2010 and $\mathrm{Zn}$ in 2011. Paper mulch increased tree leaf $\mathrm{P}$ in 2011

339 but there were no other treatment effects on tree leaf nutrients (data not shown). The tendency

340 for both compost and mulch to increase leaf K was also documented by Marsh et al. (1996) in

341 organic apple. Although Toselli et al. (2012) and de Melo et al. (2016) found no effect of

342 compost on the nutrient content of peach leaves despite increased yields. 
Leaf tissue $\mathrm{S}, \mathrm{Ca}$, and Mn frequently tested low in all treatments in this study (Mills and

345 Jones, 1996) and so all trees were amended with foliar applications of Ca and trace elements.

346 Low leaf tissue S was resolved after soil applications of S in 2010. In 2010 and 2011, leaf tissue

347 P tested above normal, although this fell back to within normal levels after compost was reduced

348 (data not shown). Low leaf tissue $\mathrm{Ca}$ is attributed to competition with $\mathrm{K}$ as well as dry and sandy

349 soil conditions, all of which were present at this site. Low leaf tissue Mn can be explained by low

350 soil availability at high soil $\mathrm{pH}$. Trefoil increased the availability of soil $\mathrm{Mn}$ in this study and

351 compost increased the availability of soil $\mathrm{Zn}$ in 2011 , although this was not reflected in increased

352 tree leaf Mn or Zn. Hashemimajd and Jamaati-e-Somarin (2011) showed use of compost

353 increased the availability and tree leaf status of $\mathrm{Zn}$ and Fe in peach grown on calcareous soil.

354 And Sorrenti et al. (2012) showed similar findings in pear. Peck et al. (2006) found organic apple

355 grown on calcareous soil deficient in $\mathrm{Zn}$, however. Further monitoring is needed to determine

356 whether long-term changes in soil nutrient availability translates into improved peach tree

357 nutritional status in calcareous soils.

358 This study design was unusual in that each treatment was treated as a discrete system

359 with respect to $\mathrm{N}$ and water inputs. The goal was to manage each system optimally by decreasing

360 fertilizer $\mathrm{N}$ inputs in treatments receiving legume $\mathrm{N}$ inputs and increasing $\mathrm{N}$ inputs when tree

361 growth was reduced (Table 2). Similarly, irrigation was targeted based on soil water drawdown

362 in each plot, ensuring water was applied optimally to each treatment. In spite of treatment

363 specific $\mathrm{N}$ and water management, we were unable to overcome the negative effects of weed

364 competition in treatments with a grass alleyway. Despite reduced external $\mathrm{N}$ inputs, trees with a

365 trefoil alleyway were largest even with significant living mulch/weed pressure in the tree-row. 
366 Research is ongoing to determine the extent to which external $\mathrm{N}$ sources can be reduced further

367 in treatments with a trefoil alleyway.

\section{Conclusions}

370 Improved methods for transition to organic production are needed to assist growers in meeting

371 the increasing demand for organic fruit. Trunk cross sectional area of newly planted peach trees

372 was initially reduced when established with living mulch as opposed to active weed management

373 in the tree-row. By the third leaf, however, trees planted with trefoil alleyways were significantly

374 larger than trees planted with grass alleyways, with no difference between trees managed with

375 tillage or weed fabric. Trunk cross sectional area in trees grown with legume alleyways was also

376 equivalent to trees of similar age managed conventionally. This suggests that trees with trefoil

377 alleyways were able to access more resources than trees with grass alleyways, despite

378 considerable weed pressure in the tree-row and reduced external inputs. Conversely, trees

379 established with grass alleyways were shown to be highly dependent on weed management in the

380 tree-row, with no difference found between trees managed with organic fertilizers and herbicide

381 and those managed conventionally. Total tree growth as indexed by trunk cross sectional area

382 was reduced substantially when paper mulch with organic vs. conventional herbicide was used,

383 allowing for the buildup of weeds over time. Increased $\mathrm{N}$ inputs did not overcome this

384 competition effect. Surface deposited legume mulch and compost positively affected soil C and

$385 \mathrm{~N}$ status. Compost when used alone to meet tree $\mathrm{N}$ needs, increased soil $\mathrm{P}$ and $\mathrm{K}$ levels to

386 unacceptable levels which necessitated the replacement of some compost applied $\mathrm{N}$ with feather

387 meal. Greater tree growth in legume treatments may be associated with greater soil N although

388 the potential for reduced tree root competition with trefoil vs. grass in the alleyways deserves 
389 further study. More research is also needed to replicate these results in a range of soil types and

390 climates. In the meantime, these findings strongly suggest that growing legumes such as

391 Birdsfoot trefoil in the alleyways could be a successful approach to establishing organic peach

392 orchards with the potential to significantly improve soil health and reduce costs associated with

393 intensive weed control and expensive external inputs.

\section{Acknowledgements}

396 This research was supported by the USDA NIFA Organic Research and Education Initiative

397 (OREI), the Utah Department of Agriculture and Food Specialty Crop Block Grant Program

398 (UDAF SCBG), the Utah Agricultural Experiment Station (UAES) and the Utah State

399 Cooperative Extension Service. Many thanks to Susan Durham for assistance with statistical

400 analysis and to Alicia Campbell, Gaia Nafziger and Leanna Hayes for technical assistance in the

401 field and laboratory. This article was approved as UAES journal paper \# 8904.

402

403

\section{Literature Cited}

404 Antonelli, M.A. Chiariotti, M.R. Tabilio, M. Ronco, and P. Di Prospero. 1997. Effects of 405 different management techniques utilized in an organic peach orchard during the training phase.

406 Acta Hort (ISHS). 465:587-592.

407

408 Alloway, B.J. 2009. Soil factors associated with zinc deficiency in crops and humans. Environ.

409 Geochem. Health. 31:537-548.

410 
411 Black, B.L. D.T. Drost, T. Lindstrom, J.R. Reeve, and G.L. Reighard. 2010. A comparison of 412 root distribution patterns among Prunus rootstocks. Journal of the American Pomological Society $413 \quad 64: 52-60$.

414

415 Bushway, L. M.P. Pritts, and D. Handley. 2008. Raspberry and Blackberry Production Guide:

416 For the Northeast, Midwest, and Eastern Canada. Natural Resource Agriculture, and

417 Engineering Service Cooperative Extension, Publication \#35.

418

419 Cardon, G.E. J. Kotuby-Amacher, P. Hole, and R. Koenig. 2008. Understanding your soil test 420 report. Utah State University Cooperative Extension publication AG/Soils/2008-01pr.

422 Cline, J. G., Neilsen, E. Hogue, S. Kuchta, and D. Neilsen. 2011. Spray-on-mulch technology for 423 intensively grown and irrigated apple orchards: influence on tree establishment, early yields, and 424 soil physical properties. HortTechnology 21:398-411.

425

426 De Melo, G.W.B., Sete, P.B. Ambrosini, V.G. Freitas, R.F. Basso, and A. Brunetto, G. 2016. 427 Nutritional status, yield and composition of peach fruit subjected to the application of organic 428 compost. Acta Scientiarum-Agronomy. 38:103-109.

429

430 Dimitri C. and L. Oberholzter. 2009. Marketing US Organic Foods. Recent Trends from Farms 431 to Consumers. USDA Economic Research Service. Economic Information Bulletin Number 58. 
433 Ernst, T., S.D. Rowley, B.L. Black and T.R. Roper. 2012. Reviewing potential local fruit

434 markets: A Utah case study. Journal of the American Pomological Society 66:16-22.

436 Ferreira I.Q., M. Angelo Rodrigues, A.M. Claro, and M. Arrobas. 2015. Management of

437 nitrogen-rich legume cover crops as mulch in traditional olive orchards. Communications in Soil

438 Science and Plant Analysis. 46:1881-1894.

439

440 Gavlak R., D. Horneck, R.O. Miller, and J. Kotuby-Amacher. 2003. Soil, Plant and Water

441 Reference Methods for the Western Region, $2^{\text {nd }}$ edn. WCC-103 Publication, Colorado State

442 University, Ft. Collins, Colorado, USA.

443 Goh, K.M., G.E. Ridgen, and M.J. Daly. 1995. Understory biomass production and biological

444 nitrogen fixation in an organic apple orchard in Canterbury, New Zealand. Communications in

445 Soil Science and Plant Analysis. 26:3261-3273.

446 Gomez-Munoz, B., D.J. Hatch, R. Bol, and R. Garcia-Ruiz. 2014. Nutrient dynamics during

447 decomposition of the residues from a sown legume or ruderal plant cover in an olive oil orchard.

448 Agriculture Ecosystems and Environment. 184: 115-123.

449 Granatstein, D. and K. Mullinix. 2008. Mulching options for Northwest organic and 450 conventional orchards. HortScience, 43:45-50.

451 Granatstein, D. and E. Sánchez. 2009. Research knowledge and needs for orchard floor 452 management in organic tree fruit systems. International Journal of Fruit Science 9:257-281. 
453 Hashemimajd, K and Jamaati-e-Somarin, S. 2011. Investigating the effect of iron and zinc 454 enriched vermicompost on growth and nutritional status of peach trees. Scientific Research and 455 Essays. 6:5004-5007

456 Hoagland, L., L. Carpenter-Boggs, D. Granatstein, M. Mazzola, F. Peryea, J. Smith, and J. 457 Reganold. 2008. Orchard floor management effects on nitrogen fertility and soil biological 458 activity in a newly established organic apple orchard. Biology and Fertility of Soils. 45:11-18.

459 Hogue, E.J., J.A. Cline, G. Neilsen and D. Neilsen. 2010. Growth and yield response to mulches 460 and cover crops under low potassium conditions in drip-irrigated apple orchards on coarse soils. 461 HortScience 45:1866-1871.

462 Layne, R.E.C., C.S. Tan and D.M. Hunter. 1994. Cultivar, ground-cover, and irrigation 463 treatments and their interactions affect long-term performance of peach trees. Journal of the 464 American Society of Horticultural Science 119:12-19.

465 Killian, J. C. and J. R. Meyer. 1982. Effect of orchard weed management on catfacing damage to 466 peaches in North Carolina. J. Econ. Entomol. 77: 1596-1600.

467 Marschner, H. 1995. Mineral nutrition of higher plants. Academic Press. San Diego, CA.

468 Marsh, K.B., M.J. Daly and T.P. McCarthy. 1996. The effect of understorey management on soil 469 fertility, tree nutrition, fruit production and apple fruit quality. Biological Agriculture and 470 Horticulture. 13, 161-173.

471 Mercelle, R. 1995. Mineral nutrition and fruit quality. Acta Hort. 383, 219-226. 
472 Merwin, I.A. and W. C. Stiles. 1994. Orchard groundcover management impacts on apple tree 473 growth and yield, and nutrient availability and uptake. Journal of the American Society of 474 Horticultural Science 119: 209-215.

475 Meyer, R.D., J. Hasey, K. Klonsky, P. Livingston, and A. Shrestha. 2006. Nitrogen management 476 during establishment of organic peaches. ASA-CSSA-SSSA 2006 International Meetings, 477 Indianapolis Nov. 12-16.

478 Mills, H.A. and J.B. Jones. 1996. Plant Analysis Handbook II: A Practical Sampling, 479 Preparation, Analysis and Interpretation Guide. Micro-Macro Publishing. Athens, Georgia. p257.

480 Mullinix, K. and D. Granatstein. 2011. Potential nitrogen contributions from legumes in Pacific 481 Northwest apple orchards. International Journal of Fruit Science 11:74-87.

482 Neilsen, G.H. and E.J. Hogue. 1992. Long-term effects of orchard soil management on tree vigor 483 and extractable soil nutrients. Canadian Journal of Soil Science 72:617-621.

485 Neilsen, G.H. and E.J. Hogue. 2000. Comparison of white clover and mixed sodgrass as orchard 486 floor vegetation. Canadian Journal of Plant Science 80:617-622.

487

488 Nunez-Elisea, R., H. Cahn, L. Caldeira and C.F. Seavert. 2005. Polypropylene row covers 489 greatly enhance growth and production of fourth-leaf sweet cherry trees. HortScience. 40:11294901129.

491 
492 Peck, G.M., P.K. Andrews, J.P. Reganold and J.K. Feldman. 2006. Apple orchard productivity

493 and fruit quality under organic, conventional and integrated management. HortScience 41:99-

494107.

495

496 Parker, M.L., J. Hull, and R.L. Perry. 1993. Orchard floor management affects peach rooting.

497 Journal of the American Society of Horticultural Science. 118:714-718.

498

499 Parker, M.L., and J.R. Meyer. 1996. Peach tree vegetative and root growth respond to orchard

500 floor management. HortScience. 31:330-333.

501

502 Perez, A. and K. Plattner. 2013. Fruit and Tree Nuts Outlook: Commodity Highlight. Organic 503 Fruit and Berries. USDA Economic Research Service. FTS-356SA.

504 Ramos, M.E., A.B. Robles, A. Sanchez-Navaro, and J.L. Gonzalez-Rebollar. 2011. Soil response 505 to different management practices in rainfed orchards in semi-arid environments. Soil and 506 Tillage Research 112:85-91.

507 Rowley, M.A., B.L. Black, C.V. Ransom, J.R. Reeve and J.E. Creech. 2011. Alternative 508 alleyways for tart cherry orchards. Journal of the American Pomological Society 64:208-217.

509 Sánchez, E.J., C.E. Edson, G.W. Bird, M.E. Whalon, T.C. Willson, K. Kizilkaya, J.E. Nugent, 510 W. Klein, A. Middleton, T.L. Loudon, D.R. Mutch, and J. Scrimger. 2003. Orchard Floor and 511 Nitrogen Management Influences Soil and Water Quality and Tart Cherry Yields. Journal of the 512 American Society of Horticultural Science 128:277-284. 
513 Skroch, W. and J.M. Shribbs. 1986. Orchard floor management: an overview. HortScience, $514 \quad 21: 390-393$.

515 Slattery, E., M. Livingston, C. Greene, and K. Klonsky. 2011. Characterisitics of Conventional 516 and Organic Apple Production in the United States. USDA Economic Research Service. FTS517 347-01. Utah Department of Agriculture and Food. 2006.

518 Sorrenti, G., M. Toselli, and B. Marangoni. 2012. Use of compost to manage Fe nutrition in Pear 519 trees grown on calcareous soil. Scientia Horticulturae 12:87-94

520 Stasiak, M.J. and Rom, R.C. 1991. Subterranean clover (Trifolium subterraneum L.). ground 521 cover effects on growth and foliar nutrient status of young peach (Prunus persica (I.) Batch). 522 HortScience, 26:77.

523 Sullivan, T.P., D.S. Sullivan, E.J. Hogue, R.A Lautenschlager and R.G. Wagner. 1998.

524 Population dynamics of small mammals in relation to vegetation management in orchard 525 agroecosystems: compensatory response in abundance and biomass. Crop Protection 17:1-11.

526 TerAvest, D., J.L. Smith, L. Carpenter-Boggs, L. Hoagland, D. Granatstein, and J.P. Reganold.

527 2010. Influence of orchard floor management and compost application timing on nitrogen

528 partitioning in apple trees. HortScience 45:637-642.

530 Toselli, M., E. Baldi, G. Marcolini, M. Quartieri, G. Sorrenti, B. Marangoni, and A. Innocenti.

531 2012. Long term (8 years) effect of mineral and organic fertilizations on peach yield and 532 nutritional status. Acta Horticulturae 962: 371-378. 
534 Tworkoski, T.J. and D.M. Glenn. 2008. Orchard Floor Management Systems. In: The Peach:

535 Botony, Production and Uses. Eds D.R. Layne and D. Bassi. CAB International.

536

537 Utah fruit and berry survey. 2006. United States Department of Agriculture National Agricultural 538 Statistics Office, Utah Field Office, Salt Lake City, UT.

539 Walsh, B.D., S, Salmins, D.J. Buszard and F. MacKenzie. 1996. Impact of soil management 540 systems on organic dwarf apple orchards and soil aggregate stability, bulk density, temperature 541 and water content. Canadian Journal of Soil Science 76:203-209.

542 Wang, H., C. Wang, X. Zhao, and F. Wang. 2015. Mulching increases water-use efficiency of 543 peach production of the rainfed semiarid Loess Plateau of China. Agricultural Water 544 Management 154:20-28.

545 Welker, W.V. and D.M. Glenn. 1991. Growth response of young peach trees to distribution 546 pattern of vegetation-free area. HortScience 26:1141-1142. 
Table 1. Compost characteristics from 2008 to 2011.

\begin{tabular}{ccccc}
\hline \hline $\begin{array}{c}\text { Compost } \\
\text { characteristic }\end{array}$ & $\begin{array}{c}\text { Chicken } \\
\text { manure }\end{array}$ & $\begin{array}{c}\text { Steer manure } \\
\mathbf{2 0 0 9}\end{array}$ & $\begin{array}{c}\text { Steer manure } \\
\mathbf{2 0 1 0}\end{array}$ & $\begin{array}{c}\text { Steer manure } \\
\mathbf{2 0 1 1}\end{array}$ \\
\hline Total N\% & 1.89 & 1.46 & 2.25 & 2.10 \\
C:N Ratio & $7: 1$ & $13: 1$ & $12: 1$ & 10.9 \\
P \% & - & 0.15 & 0.44 & 1.00 \\
K \% & - & 0.53 & 1.35 & 1.79 \\
\hline
\end{tabular}


551 Table 2. Average nitrogen inputs for compost, feather meal, and alley way biomass amendments 552 for six different orchard floor treatments: living mulch tree-row with grass (LmGr) and trefoil 553 (LmTr) alley way, straw mulch tree-row with grass ( $\mathrm{StGr}$ ) and trefoil (StTr) alley way, tillage 554 tree-row with grass alleyway (TiGr) and weed fabric with grass alley way (WfGr). Different 555 letters indicate significant differences at $\mathrm{p} \leq 0.05$.

\begin{tabular}{|c|c|c|c|c|c|}
\hline $\begin{array}{c}\text { Orchard floor } \\
\text { treatment }\end{array}$ & $\begin{array}{c}\text { Compost } \\
\text { applied per } \\
\text { tree (kg } \\
\text { DW) } \\
\end{array}$ & $\begin{array}{l}\text { Compost total } \\
\mathrm{N} \text { per tree }(\mathrm{kg})\end{array}$ & $\begin{array}{c}\text { Feather meal } \\
\text { total } \mathbf{N} \text { per } \\
\text { tree }(\mathrm{kg})\end{array}$ & $\begin{array}{c}\text { Biomass total } \\
\mathbf{N} \text { per tree } \\
(\mathbf{k g})\end{array}$ & $\begin{array}{c}\text { total average } \\
\mathrm{N} \text { inputs per } \\
\text { tree (kg) }\end{array}$ \\
\hline \multicolumn{6}{|c|}{ 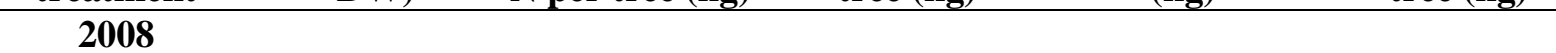 } \\
\hline LmGr & 0.91 & 0.017 & - & - & 0.017 \\
\hline LmTr & 0.91 & 0.017 & - & - & 0.017 \\
\hline StGr & 0.91 & 0.017 & - & - & 0.017 \\
\hline StTr & 0.91 & 0.017 & - & - & 0.017 \\
\hline TiGr & 0.91 & 0.017 & - & - & 0.017 \\
\hline WfGr & 0.91 & 0.017 & - & - & 0.017 \\
\hline \multicolumn{6}{|l|}{2009} \\
\hline LmGr & 1.67 & 0.024 & - & - & 0.024 \\
\hline LmTr & 1.67 & 0.024 & - & - & 0.024 \\
\hline StGr & 1.67 & 0.024 & - & - & 0.024 \\
\hline StTr & 1.67 & 0.024 & - & - & 0.024 \\
\hline TiGr & 1.67 & 0.024 & - & - & 0.024 \\
\hline WfGr & 1.67 & 0.024 & - & - & 0.024 \\
\hline \multicolumn{6}{|l|}{2010} \\
\hline LmGr & 2.55 & 0.055 & - & - & 0.055 \\
\hline LmTr & 2.54 & 0.055 & - & - & 0.055 \\
\hline StGr & 2.45 & 0.057 & - & - & 0.057 \\
\hline StTr & 2.46 & 0.057 & - & - & 0.057 \\
\hline TiGr & 2.17 & 0.049 & - & - & 0.049 \\
\hline WfGr & 1.67 & 0.037 & - & - & 0.037 \\
\hline \multicolumn{6}{|l|}{2011} \\
\hline LmGr & 2.28 & 0.051 & $0.077 \mathrm{a}$ & 0 & $0.129 \mathrm{~b}$ \\
\hline LmTr & 2.28 & 0.051 & $0.066 \mathrm{~b}$ & 0.104 & $0.318 \mathrm{a}$ \\
\hline StGr & 2.28 & 0.051 & $0.069 \mathrm{ab}$ & 0 & $0.119 \mathrm{~b}$ \\
\hline StTr & 2.28 & 0.051 & $0.064 \mathrm{~b}$ & 0.108 & $0.333 \mathrm{a}$ \\
\hline TiGr & 2.28 & 0.051 & $0.045 c$ & 0 & $0.096 \mathrm{c}$ \\
\hline WfGr & 2.28 & 0.051 & $0.050 \mathrm{c}$ & 0 & $0.101 \mathrm{c}$ \\
\hline
\end{tabular}

556 Note: trefoil biomass was mown and blown into the treerow from 2009 on, however residue 557 quantity was only collected in 2011. 
Table 3. The effectiveness of tree-row organic weed management strategies $(n=4)$, evaluated based on weed density (plants $/ \mathrm{m}^{2}$ ) and a visual evaluation of bare ground (\% cover) in 2010 in the organic experiment. Densities were determined from two $0.25 \mathrm{~m}^{2}$ quadrants in each plot. Percent bare ground was visually estimated between the three center data trees.

\begin{tabular}{|c|c|c|c|c|c|c|}
\hline \multicolumn{2}{|c|}{ Treatment } & \multicolumn{3}{|c|}{ Weed densities (no. $/ \mathrm{m}^{2}$ ) } & \multicolumn{2}{|c|}{ Bare ground $(\%)$} \\
\hline Tree-row & Alleyway & 4-May & 27-Jul & 29-Aug & 29-Jun & 27-Jul \\
\hline Straw & Grass & $20.5 \mathrm{~d}$ & $37.5 \mathrm{c}$ & $29.5 \mathrm{~b}$ & $52.7 \mathrm{~b}$ & $42.3 \mathrm{~b}$ \\
\hline Straw & Legume & $56.5 \mathrm{bc}$ & $72.5 \mathrm{~b}$ & $72.5 \mathrm{a}$ & $32.1 \mathrm{c}$ & $22.3 \mathrm{c}$ \\
\hline Alyssum & Grass & $78.0 \mathrm{ab}$ & $119.0 \mathrm{a}$ & $41.0 \mathrm{~b}$ & $18.4 \mathrm{c}$ & $13.3 \mathrm{c}$ \\
\hline Alyssum & Legume & $46.5 \mathrm{~cd}$ & $86.0 \mathrm{~b}$ & $25.5 \mathrm{~b}$ & $25.3 \mathrm{c}$ & $12.2 \mathrm{c}$ \\
\hline Tillage & Grass & $92.5 \mathrm{a}$ & $8.0 \mathrm{~d}$ & $85.5 \mathrm{a}$ & $62.0 \mathrm{~b}$ & $96.2 \mathrm{a}$ \\
\hline Weed fabric & Grass & - & - & - & $97.2 \mathrm{a}$ & $92.8 \mathrm{a}$ \\
\hline \multicolumn{2}{|c|}{$\underline{\text { Analysis of variance }}$} & \multicolumn{5}{|c|}{$(P)$} \\
\hline Block & & 0.47 & 0.49 & 0.28 & 0.70 & 0.74 \\
\hline Treatment & & $<0.0001$ & $<0.0001$ & $<0.0001$ & $<0.0001$ & $<0.0001$ \\
\hline \multicolumn{7}{|l|}{ Factorial } \\
\hline Tree-row & & 0.03 & 0.0001 & 0.08 & 0.010 & 0.010 \\
\hline Alley & & 0.84 & 0.90 & 0.16 & 0.34 & 0.14 \\
\hline Tree-row & ley & 0.002 & 0.0003 & 0.0053 & 0.08 & 0.18 \\
\hline
\end{tabular}


Table 4. The effect of conventional and organic tree-row management $(n=4)$ on weed control during the 2010 growing season, as evaluated by weed density and a visual evaluation of bare ground in the integrated experiment. Weed density was determined from two $0.25 \mathrm{~m}^{2}$ quadrants in each plot. Percent bare ground was visually estimated between the three center data trees.

\begin{tabular}{|c|c|c|c|c|c|c|c|}
\hline \multicolumn{2}{|c|}{ Treatment } & \multicolumn{4}{|c|}{ Weed density (no./m²) } & \multicolumn{2}{|c|}{ Bare ground (\%) } \\
\hline Weed management & Fertility & 4-May & 29-Jun & 27-Jul & 29-Aug & 29-Jun & 27-Jul \\
\hline Bare-ground & NPK & $56.5 \mathrm{a}$ & $29.0 \mathrm{bc}$ & $22.0 \mathrm{~b}$ & $9.0 \mathrm{bc}$ & 89.6 a & $95.1 \mathrm{a}$ \\
\hline Bare-ground & Compost & $66.5 \mathrm{a}$ & $82.5 \mathrm{a}$ & $20.0 \mathrm{~b}$ & $15.5 \mathrm{~b}$ & 89.9 a & 93.9 a \\
\hline Paper mulch & NPK & $6.0 \mathrm{~b}$ & $5.0 \mathrm{c}$ & $8.0 \mathrm{c}$ & $7.0 \mathrm{c}$ & $88.5 \mathrm{a}$ & $95.3 \mathrm{a}$ \\
\hline Paper mulch & Compost & $9.5 \mathrm{~b}$ & $34.0 \mathrm{~b}$ & $39.0 \mathrm{a}$ & $30.5 \mathrm{a}$ & $76.8 \mathrm{~b}$ & $78.9 \mathrm{~b}$ \\
\hline $\begin{array}{l}\text { Analysis of } \\
\underline{\text { variance }}\end{array}$ & & & & & $P)$ & & \\
\hline Block & & 0.15 & 0.23 & 0.08 & 0.69 & 0.57 & 0.55 \\
\hline Treatment & & $<0.0001$ & 0.0004 & $<0.0001$ & $<0.0001$ & 0.0074 & $<0.0001$ \\
\hline $\begin{array}{c}\text { Factorial } \\
\text { weed }\end{array}$ & & & & & & & \\
\hline management & & $<0.0001$ & 0.003 & 0.58 & 0.02 & 0.02 & 0.001 \\
\hline Fertility & & 0.33 & 0.0008 & 0.003 & $<0.0001$ & 0.048 & 0.0003 \\
\hline Weed $\mathrm{x}$ fertility & & 0.64 & 0.27 & 0.001 & 0.004 & 0.04 & 0.0009 \\
\hline
\end{tabular}


564 Figure 1: Trunk cross sectional area over time $(n=4)$ for organic peach trees established in 2009 under different orchard floor management systems: straw mulch grass alleyway ( $\mathrm{StGr}$ ), straw mulch trefoil alleyway (StTr), living mulch grass alleyway (LmGr), living mulch trefoil alleyway 568 Different letters indicate significant differences among treatments within a year at the level of $p$ $569<0.05$.

Figure 2: Trunk cross sectional area over time $(n=4)$ for peach trees established in 2008 under different integrated orchard floor management systems: organic fertilizer conventional herbicide $(\mathrm{OFH})$, conventional fertilizer conventional herbicide $(\mathrm{CFH})$, conventional fertilizer conventional herbicide to start transition to organic in 2011 (CFHT), organic fertilizer paper mulch (OFM), conventional fertilizer paper mulch (CFM). Different letters indicate significant differences at the level of $p<0.05$.

Figure 3: Total organic soil carbon $(0-10 \mathrm{~cm}$ depth) in the organic experiment for alleyway main effect over time $(n=4)$ contrasted with organic weed free standards tillage and weed fabric. Different letters indicate significant differences at the level of $p<0.05$.

Figure 4: Total soil nitrogen $(0-10 \mathrm{~cm}$ depth) in the organic experiment for alleyway main effect over time $(n=4)$ contrasted with organic weed free standards tillage and weed fabric. Different letters indicate significant differences at the level of $\mathrm{p}<0.05$.

582 Figure 5: Main effect of fertilizer and interaction of weed control method with time in the 583 integrated experiment on soil organic carbon $(n=4)$. Different letters indicate significant 584 differences at the level of $\mathrm{p}<0.05$.

Figure 6: Available (Olsen) soil phosphorus for tree-row main effect over time $(n=4)$ in the organic experiment contrasted with organic weed free standards tillage and weed fabric. Different letters indicate significant differences at the level of $p<0.05$.

588 Figure 7: Available (Olsen) soil potassium for tree-row and alleyway main effect over time ( $\mathrm{n}=$ 589 4) in the organic experiment contrasted with organic weed free standards tillage and weed fabric. 590 Different letters indicate significant differences at the level of $\mathrm{p}<0.05$. 


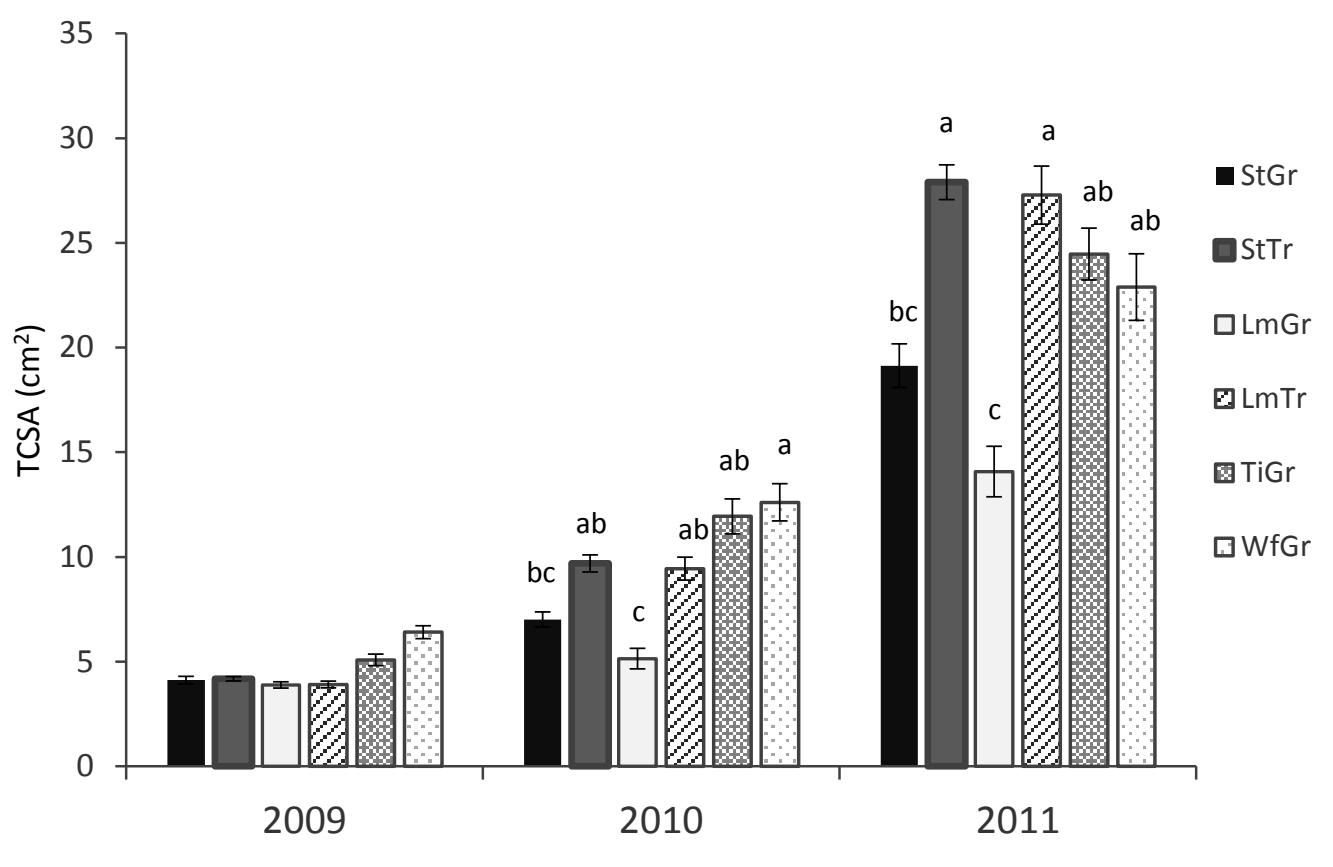

596 Figure 1.

597 


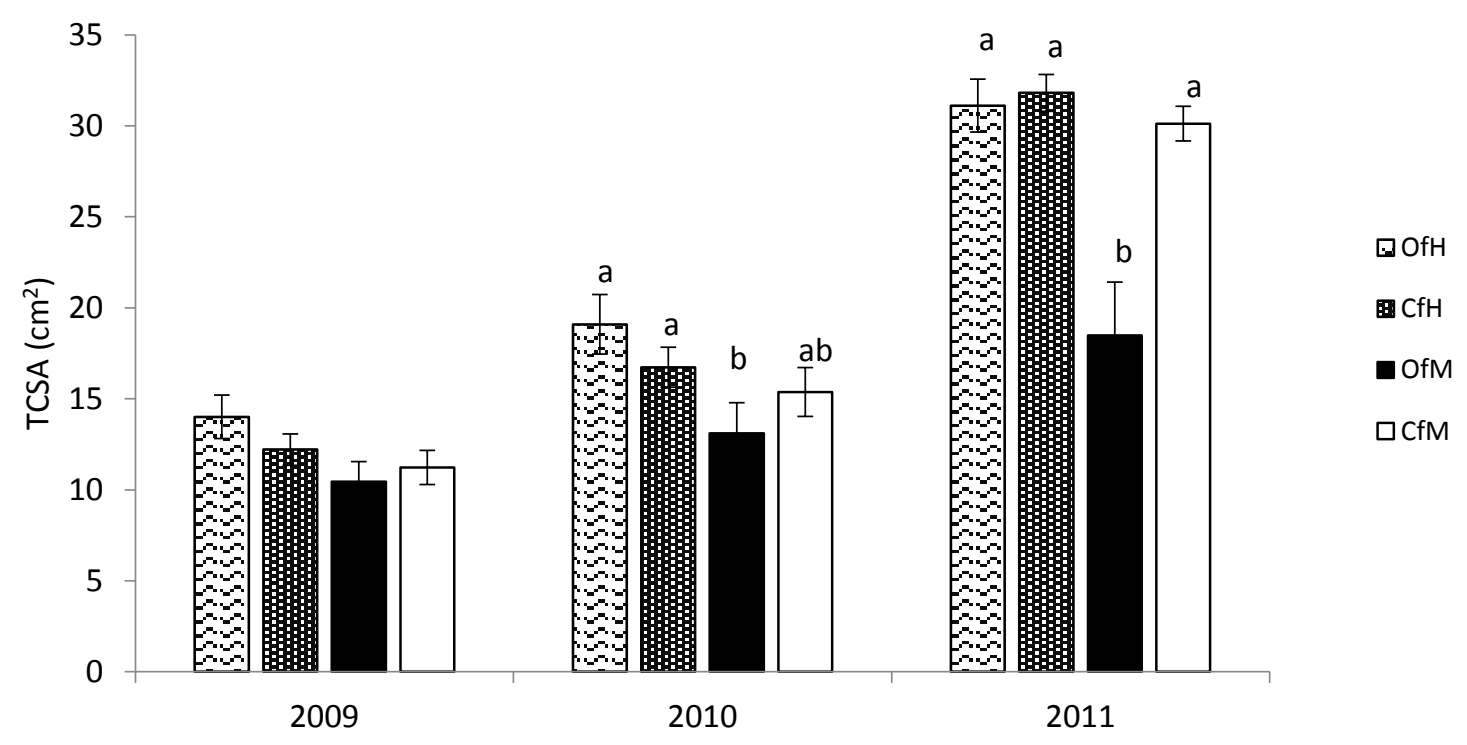

599

600 Figure 2.

601 


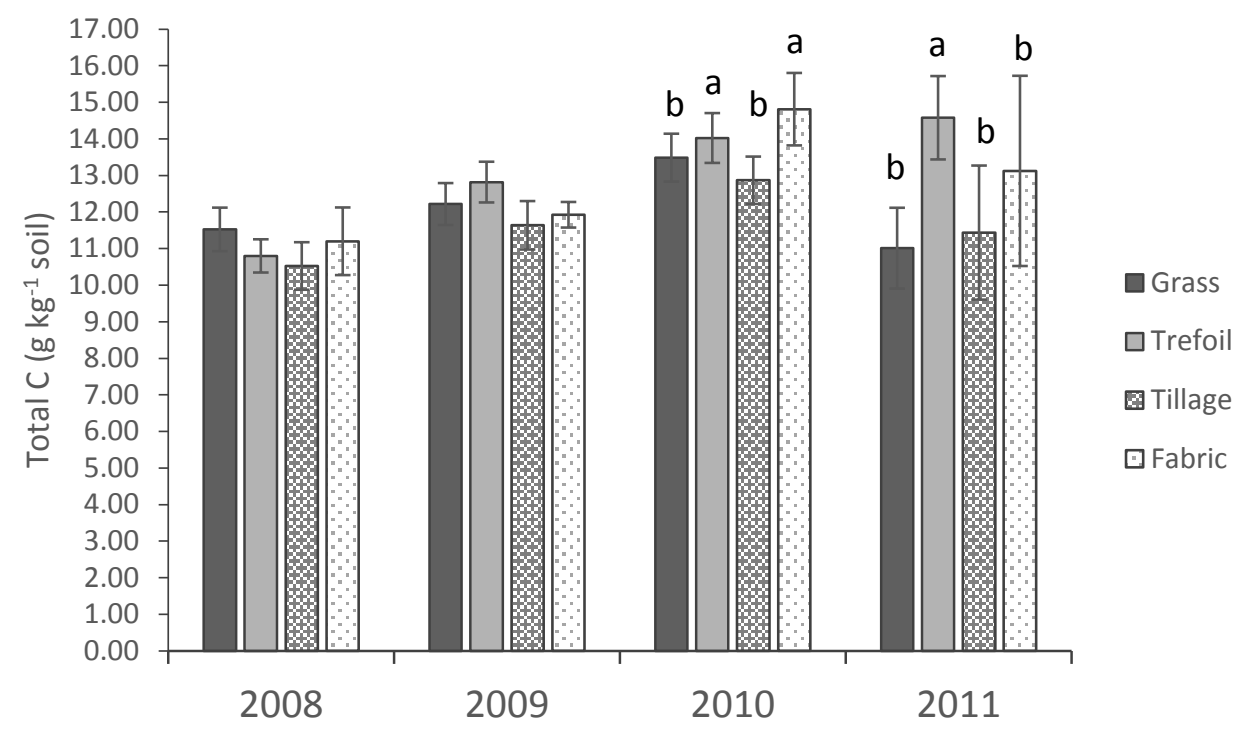

603 Figure 3.

604 


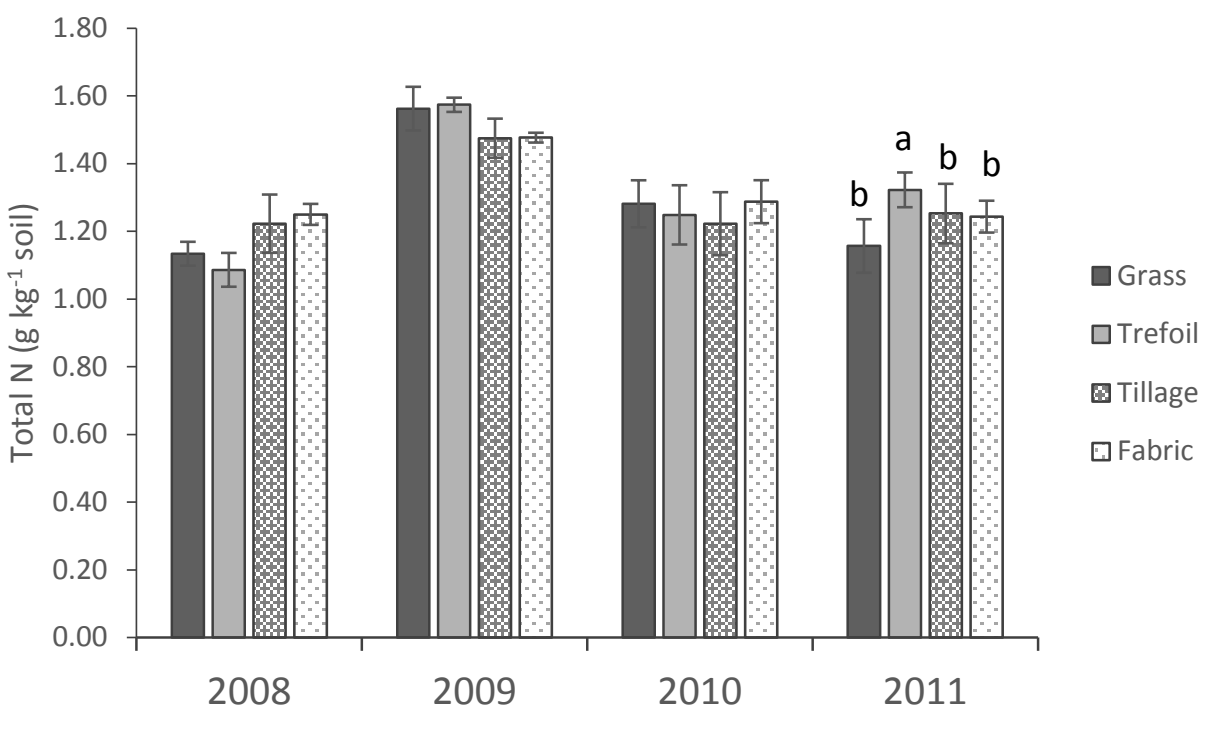

606 Figure 4

607 

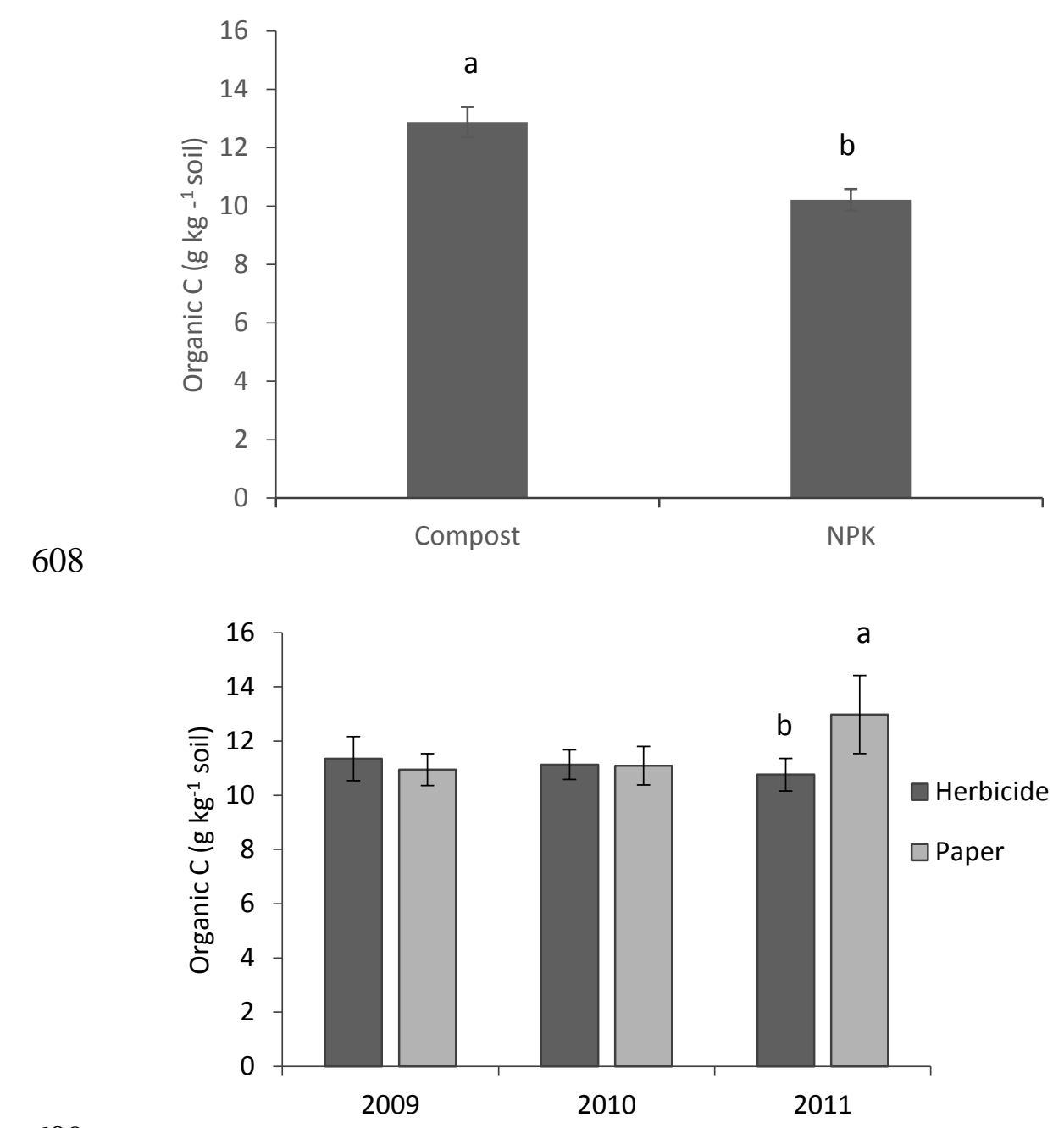

609

610 Figure 5.

611 


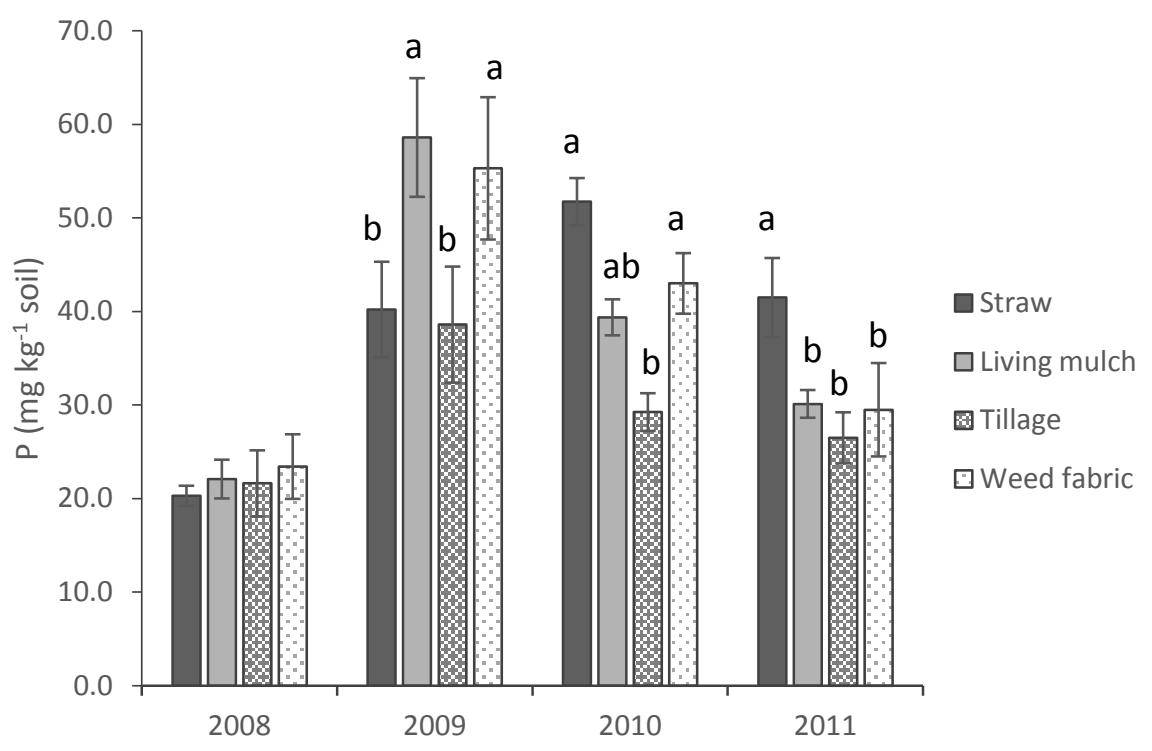

612

613 Figure 6.

614 


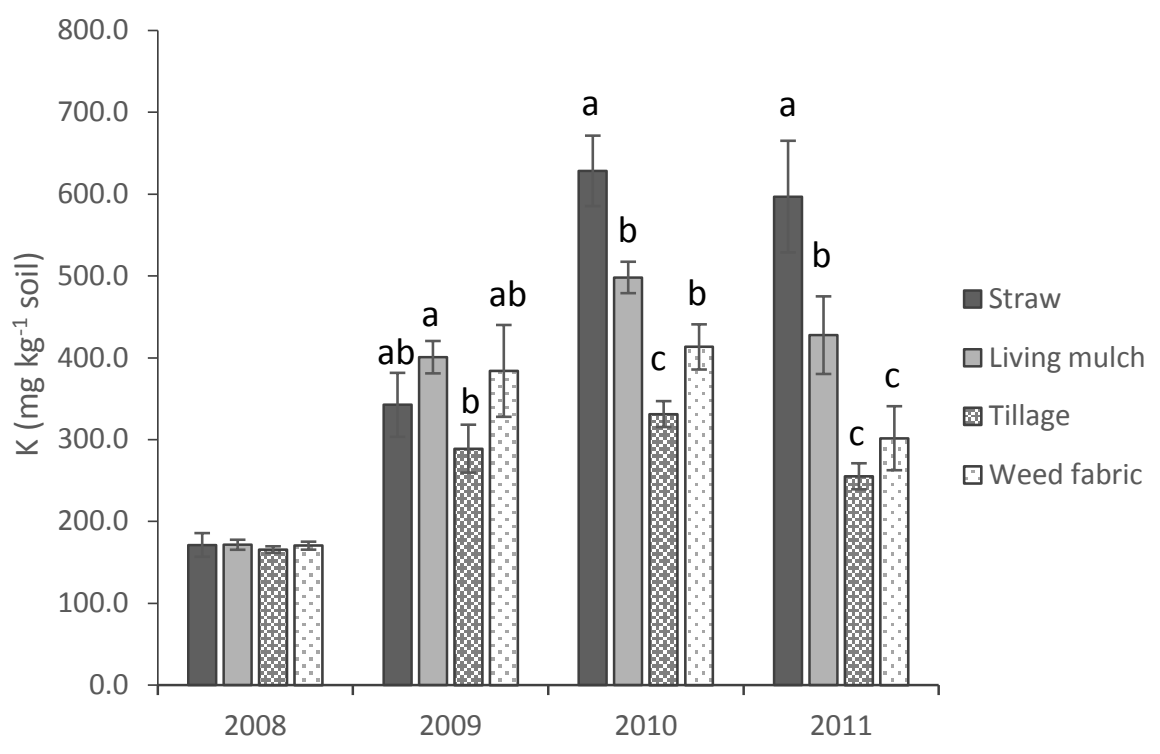

615

616

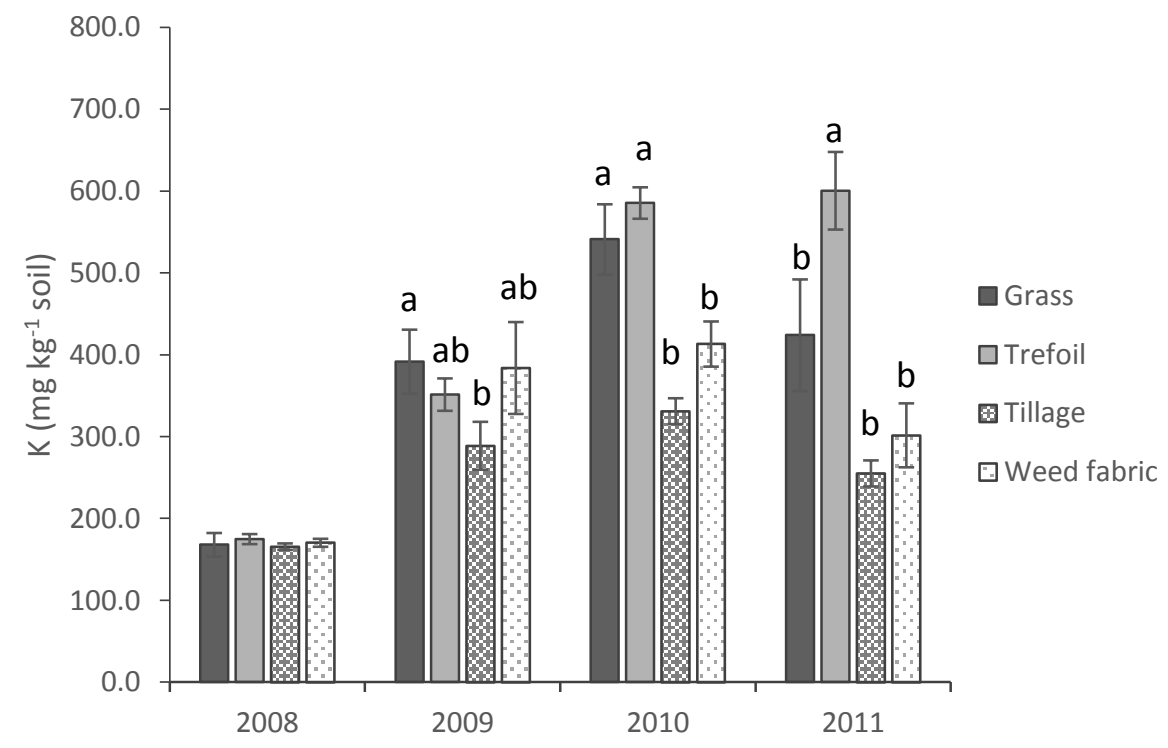

617 Figure 7.

618

619

620 